\title{
Kebijakan Penetapan Harga Pada Pt. Atrindo Asia Global Bandung
}

\author{
Sukmayadi \\ STIE Sebelas April Sumedang \\ e-mail : sukmayadibaihaqi@gmail.com
}

\begin{abstract}
ABSTRAK
Penelitian ini untuk menganalisis fokus permasalahan: Kebijakan Penetapan Harga Pada PT. Atrindo Asia Global Bandung, dengan tujuan untuk mengetahui pelaksanaan pelaksanaan kebijakan penetapan harga, kendala dan solusi kebijakan penetapan harga pada PT. Atrindo Asia Global Bandung. Penelitian ini menggunakan Metode Kualitatif dengan variabel mandiri: Harga. Teknik sampel yang digunakan adalah Purposive Sampling, yaitu teknik pengambilan sampel sumber data dengan pertimbangan tertentu. .Pelaksanaan kebijakan penetapan harga pada PT. Atrindo Asia Global diharapkan dapat terlaksana dengan baik sehingga mampu mencapai target perusahaan.
\end{abstract}

Kata kunci: Penetapan harga

\begin{abstract}
This study is to analyze the focus of the problem: Pricing Policy at PT. Atrindo Asia Global Bandung, with the aim to find out the implementation of pricing policies, constraints and pricing policy solutions at PT. Atrindo Asia Global Bandung. This study uses a Qualitative Method with an independent variable: Price. The sampling technique used is Purposive Sampling, which is a data source sampling technique with certain considerations. Implementation of pricing policies at PT. Atrindo Asia Global is expected to be implemented well so that it is able to achieve the company's targets.
\end{abstract}

Keyword: pricing policies

\section{PENDAHULUAN}

Semua perusahaan yang bergerak di sektor industri produk maupn jasa harus semakin membuka diri dalam menerima perubahan akibat kemajuan dan perkembangan yang terjadi. Dalam masa persaingan saat ini, menyadari pemasaran semata-mata tidak hanya melakukan proses penjualan saja, akan tetapi juga harus menuntut kejelian perusahaan dalam menerapkan suatu kebijakan yang akan dibuatnya.

Mantan menteri perdagangan Mari Eka Pangestu dalam republica.co.id menuturkan bahwa perusahaan jasa memiliki potensi besar untuk meningkatkan pertumbuhan ekonomi Indonesia. Menurutnya, sektor ini dapat berkontribusi terhadap peningkatan.

Produk Domestik Bruto (PDB) nasional, penciptaan lapangan kerja, dan pengurangan kemiskinan. Ia mengatakan bahwa, perusahaan jasa dapat berkontribusi meningkatkan PDB nasional sebesar 55 persen dari tahun 2012. Mari memandang kebijakan pemerintah saat ini semakin mendukung pertumbuhan sektor jasa. Salah satunya dengan kebijakan Indonesia yang telah menyepakati Asean Framework Agreement on Services (AFAS) yang merupakan persetujuan dan kerjasama dalam rangka liberalisasi perdagangan bidang jasa dalam forum ASEAN.

Kotler dan Keller dalam Tjiptono (2014:26) menyatakan perusahaan jasa adalah setiap tindakan atau perbuatan yang dapat ditawarkan oleh suatu pihak kepada pihak lain yang pada dasarnya bersifat intangible (tidak berwujud fisik) dan tidak menghasilkan kepemilikan sesuatu. PT Atrindo Asia Global yang bergerak di bidang jasa pengendalian hama, berlokasi di Jalan Cipamokolan Komplek Bandung Indah Raya Blok A-5 No. 8 RT/RW 001/01 Mekarjaya Kecamatan Rancasari Kota Bandung. PT. Atrindo Asia Global memiliki berbagai jenis layanan pengendalian untuk setiap jenis hama yaitu Pest Control seperti Rodent Control dan Fumigasi. Dengan menetapkan harga yang terjangkau membuat PT. Atrindo Asia Global 
mudah menarik minat konsumen khususnya Residensial, Komersial, Industrial, Medikal, Institusional dan Transportasional. PT. Atrindo Asia Global bermitra dengan beberapa customer diantaranya Kitchen Checo, Awani Studento, Giant Extra, PT. Trifa Raya Laboratories, PT. Errita Pharma Ceutical, PT. Gramedia Printing, Lion Superindo dan lain-lain sehingga dapat bersaing dengan perusahaan lain yang bergerak dibidang yang sejenis.

W.J Stanton dalam Mursid (2017:26) menyatakan pemasaran meliputi keseluruhan kegiatan-kegiatan usaha, yang bertujuan merencanakan, menentukan harga, hingga mempromosikan dan mendistribusikan barangbarang atau jasa yang akan memuaskan kebutuhan pembeli, baik yang aktual maupun yang potensial. Sementara Tjiptono (2014:41-42) menyatakan bauran pemasaran merupakan seperangkat alat yang digunakan pemasar untuk membentuk karakteristik jasa yang ditawarkan kepada pelanggan. Tjiptono merumuskan bauran pemasaran menjadi 7P yaitu Product, Price, Promotion, Place, People, Process, Physical Evidence. Untuk mencapai tujuan pemasaran, maka pelaksanaan kegiatan pemasaran, perusahaan mengkombinasikan 7 variabel tersebut mendukung satu sama lain dalam menentukan strategi pemasaran dengan kata lain variabel-variabel marketing mix harus dipadukan untuk mencapai tujuan yang telah ditetapkan.

Agar dapat sukses dalam memasaran suatu produk, setiap perusahaan harus menetapkan harganya secara tepat. Tjiptono (2015:289) menyatakan bahwa harga merupakan satu-satunya unsur bauran pemasaran yang mendatangkan pemasukan atau pendapatan bagi perusahaan, sedangkan ketiga unsur lainnya (produk, distribusi dan promosi) menyebabkan timbulnya biaya. Selain itu harga merupakan unsur bauran pemasaran yang fleksibel, artinya dapat diubah dengan cepat. Tjiptono (2015:291) menyatakan ada beraneka ragam tujuan penetapan harga yaitu : (1) Tujuan berorientasai pada laba yaitu memaksimalkan laba perusahaan, (2) Tujuan berorientasi pada volume yaitu harga ditetapkan sedemikian rupa agar dapat mencapai target volume penjualan, (3) Tujuan berorientasi pada citra yaitu perusahaan dapat menetapkan harga tinggi untuk membentuk atau mempertahankan citra perusahaan namun sebaliknya harga rendah dapat dipergunakan untuk untuk membentuk citra nilai tertentu, (4) Tujuan stabilisasai harga yaitu bertujuan untuk mempertahankan hubungan yang stabil antara harga suatu perusahaan dengan harga pemimpin industri (industry leader), (5) Tujuantujuan lainnya yaitu bertujuan untuk mencegah masuknya pesaing, mempertahankan loyalitas pelanggan, mendukung penjualan ulang atau menghindari campur tangan pemerintah.
Berdasarkan hasil observasi sementara, penulis mendapatkan informasi mengenai penetapan harga PT. Atrindo untuk mempertahankan loyalitas pelanggan, PT Atrindo Asia Global berusaha memaksimumkan daya tarik pelanggannya guna mendapatkan banyak pengguna jasa. Penetapan harga dilakukan dengan tujuan berorientasi pada volume dikarenakan target volume penjualan merupakan tujuan PT. Atrindo Asia Global ditambah dengan semakin banyaknya perusahaan yang bergerak di bidang yang sama, maka PT Atrindo Asia Global berupaya menyelaraskan permintaan dan penawarannya guna memenuhi pencapaian target volume penjualan, nilai penjualan, atau pangsa pasar. Perusahaan diharuskan mampu bersaing dengan lebih baik dari segi penetapan harga guna medapatkan banyak konsumen. Penetapan harga berdasarkan persaingan dianggap umum dikarenakan banyaknya kompetitor, perusahaan kerap mendapatkan kesulitan dalam menentukan biaya per unit secara akurat. Hal ini menyulitkan perusahaan apabila ingin merubah harganya tanpa menimbulkan reaksi pesaing.

\section{Rumusan Masalah}

Berdasarkan latar belakang penelitian yang telah diuraikan di atas dapat dirumuskan permasalahan bagaimana pelaksanaan kebijakan penetapan harga pada PT. Atrindo Asia Global Bandung dan apa kendala dan solusi kebijakan penetapan harga pada PT. Atrindo Asia Global Bandung

Penelitian ini dibatasi dan difokuskan pada kebijakan penetapan harga pada PT. Atrindo Asia Global Bandung.

Adapun tujuan yang ingin dicapai dalam penelitian ini yaitu untuk mengetahui pelaksanaan kebijakan penetapan harga Pada PT. Atrindo Asia Global Bandung dan mengetahui kendala dan solusi kebijakan penetapan harga pada PT. Atrindo Asia Global Bandung.

Manfaat dari penelitian ini antara lain menambah wawasan kajian dan berbagai analisis yang dilakukan, sekaligus sebagai media berbagi wawasan mengenai penelitian bidang kajian manajemen pemasaran pada umumnya dan penetapan harga pada khususnya, sedangkan untuk perusahaan yaitu PT Atrindo Asia Global Bandung sebagai informasi yang bermanfaat dan dapat dijadikan masukan yang kontruktif dalam melaksanakan kegiatan-kegiatan perusahaan dimasa sekarang maupun dimasa yang akan dating. Dan informasi yang dihasilkan dapat diimplementasikan dalam menyusun strategi usaha dalam meningkatkan penjualan dan memperoleh laba perusahaan yang lebih baik lagi.

Selain pihak-pihak diatas tentunya ada pihak lain yang tidak tersebutkan satu persatu dan 
diharapkan bermanfaat dalam memberikan bahan bacaan atau referensi tentang analisis strategi pemasaran khusunya tentang kebijakan penetapan harga.

\section{METODOLOGI PENELITIAN}

Penelitian ini menggunakan metode penelitian kualitatif atau naturalistik, karena dilakukan pada kondisi alamiah. Sugiyono (2017:9) menyatakan bahwa metode penelitian kualitatif adalah metode penelitian yang berlandaskan pada filsafat postpositivisme, digunakan untuk meneliti pada kondisi objek yang alamiah, (sebagai lawannya yaitu eksperimen) dimana peneliti adalah sebagai instrumen kunci, teknik pengumpulan data dilakukan secara triangulasi (gabungan), analisis data bersifat induktif, dan hasil penelitian kualitatif lebih menekankan makna dari pada generalisasi.

Penelitian dilakukan pada PT. Atrindo Asia Global Bandung yang beralamat di Jalan Cipamokolan Komplek Bandung Indah Raya Blok A5-8, Rt/Rw. 001/01 Kelurahan Mekarjaya Kecamatan Rancasari Bandung.

Untuk teknik pengumpulan data dengan cara studi kepustakaan, studi ini dilakukan dengan cara mengumpulkan data melalui buku-buku dan arsip yang penulis dapatkan dari perpustakaanperpustakaan ataupun arsip-arsip yang peneliti Bandung. peroleh dari PT. Atrindo Asia Global

Dan untuk prosedur pengumpulan data digunakan data data primer dan data sekunder. Data Primer Sugiyono (2017:225) menyatakan data primer adalah data yang langsung memberikan data kepada pengumpul data, yang berkaitan dengan penelitian (dokumen, arsip, dan lainnya) dan hasil pengamatan di lokasi. Sementara data sekunder. Sugiyono (2017:225) menyatakan data sekunder adalah data yang diperoleh secara tidak langsung kepada pengumpul data, yaitu dari buku, serta arsip arsip atau dokumen-dokumen, situs internet, serta literatur-literatur yang didapat dari berbagai informasi yang dimiliki PT. Atrindo Asia Global Bandung.

Untuk teknik dan prosedur analisis data pada penelitian ini, penelit menggunakan metode Miles dan Huberman. Milles dan Huberman dalam Sugiyono (2017:246) menyatakan bahwa terdapat tiga macam kegiatan analisis data kualitatif, yaitu data reduction (data reduksi), data display, dan conclusions drawing/verifying.

\section{a. Reduksi.}

Mereduksi data berarti merangkum, memilih hal-hal pokok, memfokuskan pada hal-hal yang penting dicari tema dan polanya dan membuang yang tidak perlu. Sugiyono (2017:247) menyatakan bahwa data yang diperoleh di lapangan jumlahnya sangat banyak, untuk itu perlu dicatat secara teliti dan rinci. Data yang telah direduksi akan memberikan gambaran yang jelas dan mempermudah peneliti untuk melakukan pengumpulan data selanjutnya, dan mencarinya bila diperlukan. Reduksi data bisa dibantu dengan alat elektronik seperti komputer, dengan memberikan kode pada aspek-aspek tertentu. Dengan reduksi maka peneliti merangkum, mengambil data yang penting, membuat kategorisasi, berdasarkan huruf besar, huruf kecil dan angka. Data yang tidak penting dibuang.

\section{b. Penyajian Data (Data Display)}

Setelah data reduksi, makalangkah berikutnya adalah mendisplaykan data. Display data dalam peneliitan kualitatif dapat dilakukan dalam bentuk: uraian singkat, bagan, hubungan antar kategori, flowchart, dan sebagainya.

Miles dan Huberman dalam Sugiyono (2017:249) menyatakan bahwa yang paling sering digunakan untuk menyajikan data dalam penelitian kualitatif dengan teks bersifat naratif. Selain dalam bentuk naratif, display data juga dapat berupa grafik, matriks, network (jejaring kerja).

\section{c. Verifikasi Kesimpulan (Conclusion Drawing)}

Miles dan Huberman dalam Sugiyono (2017:252) menyatakan bahwa langkah ketiga adalah penarikan kesimpulan dan verifikasi. Kesimpulan awal yang dikemukakan masih bersifat sementara, dan akan berubah bila tidak ditemukan bukti-bukti yang kuat yang mendukung pada tahap pengumpulan data berikutnya. Namun bila kesimpulan memang telah didukung oleh bukti-bukti yang valid dan konsisten saat peneliti ke lapangan mengumpulkan data, maka kesimpulan yang dikemukakan merupakan kesimpulan yang kredibel (dapat dipercaya).

Selanjutnya dilakukan pemeriksaan keabsahan data. Sugiyono (2017:267) menyatakan bahwa uji keabsahan data dalam penelitian kualitatif ditekankan pada uji validasi dan reliabilitas. Dalam penelitian kualitatif kriteria utama terhadap data hasil penelitian adalah valid, kredibel, dan objek. 


\section{HASIL DAN PEMBAHASAN}

Berdasarkan analisis data yang telah diperoleh dari informan Kebijakan Penetapan Harga produk pelayanan jasa pest control di PT. Atrindo Asia Global Bandung, maka dapat diuraikan hasil penelitian sebagai berikut :

Pengumpulan Data (Data Collection) dilakukan untuk memperoleh informasi yang

Reduksi Data (Data Reduction) diperoleh dari lapangan jumlahnya cukup banyak, untuk itu perlu dicatat secara teliti dan rinci. Seperti telah dikemukakan, semakin lama peneliti ke lapangan, maka jumlah data akan semakin banyak, kompleks, dan rumit. Untuk itu perlu segera dilakukan analisis data. Mereduksi data berarti merangkum, memilih hal-hal yang pokok, memfokuskan pada hal-hal penting, dicari tema dan polanya. Data yang diperoleh dari hasil wawancara dan observasi langsung pada PT. Atrindo Asia Global Bandung diuraikan dalam bentuk uraian secara rinci, kemudian disederhanakan dan difokuskan dalam hal-hal yang penting berikut : 1) Saticfaction Based Pricing ( Harga berdasarkan kepuasan). Perusahaan menetapkan harga berdasarkan kepuasan dari para konsumen atau pengguna layanan jasa. Dalam menetapkan harga berdasarkan kepuasan konsumennya perusahaan memberikan garansi jasa kepada pelanggan diluar service sebanyak 4 kali dalam sebulan, menginformasikan harga secara jelas dengan diberikannya daftar harga, dan memberikan nilai tambah kepada pelanggan dengan cara memberikan presentasi dan in house training kepada konsumen. 2). Relationship Pricing (Harga berdasarkan hubungan). Perusahaan menetapkan harga berdasarkan hubungan antar pelanggan, diantaranya dengan dilakukannya kontrak jangka panjang yaitu selama 1 tahun dan 6 bulan kontrak. dengan pelanggan dan memberikan layanan paket jasa (price dibutuhkan dalam rangka mencapai tujuan peneliitan. Data yang diperoleh dari hasil wawancara dengan Service Supervisor, Staf Marketing dan observasi secara langsung tersebut kemudian disimpulkan dan diambil bagian-bagian pokok dari permasalahan yang telah diuraikan yaitu mengenai kebijakan penetapan harga.

bundling) yaitu paket treatment serangga dan tikus. 3). Efficiency Pricing (Harga berdasarkan efisiensi). Perusahaan menetapkan harga berdasarkan keefisienan dimana perusahaan mengelola dan menekan biaya rendah secara efisien, struktur biaya yang cukup sulit ditiru oleh para pesaing. 4). Cost Based pricing (Harga berdasarkan pada biaya dan laba yang diharapkan) Perusahaan tidak menggunakan perhitungan biaya tetap, variabel, dan semi variabel. Perusahaan berusaha menyesuaikan dan mengefisienkan biaya penuh (full cost) yang dikeluarkan dan berusaha untuk tetap berhemat dan tidak menggunakan hitungan matematis biaya tetap, biaya variabel dan biaya semi variabel. 5). Competition based pricing (Harga berdasarkan pada persaingan) Harga yang ditawarkan oleh perusahaan kerap disamai oleh para pesaing sehingga perusahaan menerapkan tarif yang standar. 6).Demand based pricing (Harga berdasarkan permintaan) Perusahaan menetapkan harga berdasarkan permintaan harga dari para pelanggan sehingga menimbulkan adanya negosiasi, memberikan diskon sebesar $20 \%$ dari tarif normal pada hari hari besar, serta memberikan harga sesuai dengan segmentasi pasar diantaranya residensial, komersial, industrial, medical dan trasportational.

Penyajian Data (Display Data) Setelah data direduksi maka langkah selanjutnya adalah mendisplaykan data, kemudian membuat kesimpulan/verifikasi. 


\section{Tabel 1}

Display Data

\begin{tabular}{|c|c|c|c|}
\hline \multirow[t]{2}{*}{ No } & \multicolumn{2}{|l|}{ Teori } & \multirow[t]{2}{*}{ Display } \\
\hline & Dimensi & Indikator & \\
\hline 1 & $\begin{array}{l}\text { Saticfaction Based Pricing } \\
\text { (Harga berdasarkan kepuasan) }\end{array}$ & $\begin{array}{l}\text { 1. Memberikan garansi jasa } \\
\text { kepada pelanggan } \\
\text { 2. Menetapkan harga secara } \\
\text { eksplisit } \\
\text { 3. Memberikan nilai tambah } \\
\text { kepada pelanggan }\end{array}$ & $\begin{array}{l}\text { Garansi Jasa diberikan diluar setelah } 4 \text { kali } \\
\text { treatment, pelanggan diberikan daftar harga } \\
\text { (price list) dan memberikan } \\
\text { presentasi dan inhouse trainingsebagai nilai } \\
\text { tambah. }\end{array}$ \\
\hline 2 & $\begin{array}{l}\text { Relationship Pricing } \\
\text { (Harga berdasarkan hubungan) }\end{array}$ & $\begin{array}{l}\text { 4. Long term contracts } \\
\text { (Kontrak jangka panjang) } \\
\text { 5. Price Bundling } \\
\text { (Harga } \\
\text { paket/bundel) }\end{array}$ & $\begin{array}{l}\text { Kontrak jangka panjang dengan pelanggan } \\
\text { selama } 1 \text { tahun dan } 6 \text { bulan kontrak, } \\
\text { menawarkan paket jasa yaitu pest control } \\
\text { dan rodent control sekaligus. }\end{array}$ \\
\hline 3 & $\begin{array}{l}\text { Efficiency Pricing (Harga } \\
\text { berdasarkan efisiensi) }\end{array}$ & $\begin{array}{l}\text { 6. Cost leader pricing } \\
\text { (strategi biaya rendah) } \\
\text { 7. Struktur biaya sulit ditiru } \\
\text { pesaing } \\
\text { 8. } \begin{array}{l}\text { Penghematan biaya } \\
\text { terhadap persepsi } \\
\text { positif nilai produk }\end{array}\end{array}$ & $\begin{array}{l}\text { Mengelola dan menekan biaya rendah } \\
\text { secara efisien, struktur biaya yang cukup } \\
\text { sulit ditiru oleh para pesaing. }\end{array}$ \\
\hline 4 & $\begin{array}{l}\text { Cost Based pricing (Harga } \\
\text { berdasarkan pada biaya dan laba } \\
\text { yang diharapkan) }\end{array}$ & $\begin{array}{ll}\text { 9. } & \text { Biaya tetap } \\
\text { 10. } & \text { Biaya variabel } \\
\text { 11. } & \text { Biaya semi variabel }\end{array}$ & $\begin{array}{l}\text { Tidak menggunaan hitungan biaya tetap, } \\
\text { biaya variabel dan semi variabel. } \\
\text { Menyesuaikan full cost dengan pelaksanaan } \\
\text { treatment }\end{array}$ \\
\hline 5 & $\begin{array}{l}\text { Competition based pricing } \\
\text { (Harga berdasarkan pada } \\
\text { persaingan) }\end{array}$ & $\begin{array}{l}\text { 12. Price signaling } \\
\text { 13. Going rate pricing }\end{array}$ & $\begin{array}{l}\text { Menetapkan harga secara standar dan sesuai } \\
\text { dengan harga di pasaran }\end{array}$ \\
\hline 6 & $\begin{array}{l}\text { Demand based pricing } \\
\text { (Harga berdasarkan permintaan) }\end{array}$ & $\begin{array}{l}\text { 14. Discounting } \\
\text { 15. Market } \\
\text { Segmentation } \\
\text { Pricing }\end{array}$ & $\begin{array}{l}\text { Diskon diberikan sebesar } 20 \% \\
\text { pada hari hari tertentu, serta menetapkan } \\
\text { harga sesuai dengan pasar sasaran yang } \\
\text { dibidik }\end{array}$ \\
\hline
\end{tabular}

Sumber: Fandy Tjiptono (2014), yang kemudian diselesaikan oleh penulis

Tabel 2

Penarikan Kesimpulan (Verification)

\begin{tabular}{cl}
\hline No & \multicolumn{1}{c}{ Kesimpulan } \\
\hline 1 & $\begin{array}{l}\text { Memberikan Garansi Jasa setelah } 4 \text { kali treatment inti dan memberikan daftar harga (Price List) serta } \\
\text { memberikan in-house training }\end{array}$ \\
2 & $\begin{array}{l}\text { Kontrak dilakukan selama } 1 \text { tahun dan } 6 \text { bulan dan memberikan } \\
\text { price bundling }\end{array}$ \\
3 & $\begin{array}{l}\text { Menekan biaya seefisien mungkin dan struktur biaya cukup sulit di tiru pesaing } \\
4\end{array}$ \\
& $\begin{array}{l}\text { Tidak menggunakan hitungan biaya tetap, biaya variabel, dan } \\
\text { biaya semi variabel. Menyesuaikan full cost setiap pelaksanaan treatment kepada pelanggan }\end{array}$ \\
5 & Menetapkan harga secara standar \\
6
\end{tabular}




\section{Temuan Penelitian}

Adapun temuan-temuan yang ditemukan tentang kebijakan penetapan harga yang dilakukan sebagai berikut:

1. PT. Atrindo Asia Global Bandung menetapkan harga berdasarkan kepuasan konsumen (satisfaction based pricing) yang berarti berorientasi pada volume penjualan dan mempertahankan loyalitas pelanggan. Kemudian PT. Atrindo Asia Global Bandung menetapkan harga dengan menerapkan 3 bentuk implementasi harga berdasarkan kepuasan yaitu Service Guarantees, benefit driven pricing, dan flat rate pricing dimana harga produk ditetapkan berdasarkan kepuasan dari para pengguna jasa PT. Atrindo Asia Global Bandung.

2. PT. Atrindo Asia Global Bandung menertapkan Long term contract dengan para pelanggannya selama satu tahun kontrak jangka panjang dan 6 bulan kontrak jangka pendek. Dan menetapkan price bundling PT. Atrindo Asia Global Bandung menawarkan beberapa paket layanan treatment hama sesuai dengan kebutuhan pelanggannya.

3. PT. Atrindo Asia Global Bandung menetapkan harga berdasarkan keefisienan dimana perusahaan mengelola dan menekan biaya rendah mungkin tetapi tetap memberikan pelayanan yang prima dan memuaskan kepada para pengguna jasa.

4. PT. Atrindo Asia Global Bandung berusaha menyesuaikan dan mengefisienkan biaya penuh (full cost) yang dikeluarkan serta tidak menggunakan hitungan berdasarkan biaya tetap, variabel dan semi variabel.

5. PT. Atrindo Asia Global menetapkan harga berdasarkan persaingan (competition based pricng) yaitu menetapkan harga secara standar yaitu tidak terlalu mahal dan tidak terlalu murah. Hal tersebut berarti PT. Atrindo Asia Global menggunakan metode Customary Pricing karena penetapan harga berpegang teguh pada tingkat harga tradisional dan tidak mengubah harga di luar batas-batas yang diterima.

6. PT. Atrindo Asia Global Bandung menetapkan harga berdasarkan permintaan harga dari para pelanggan sehingga menimbulkan adanya negosiasi dan pada hari hari tertentu memberikan diskon sebesar $20 \%$ dan menetapkan harga nya sesuai dengan tingkat kesulitan dan segmentasi usaha para pelanggannya.

\section{Kendala yang dihadapi PT. Atrindo Asia Global} Bandung

Adapun kendala-kendala yang dihadapi dalam kebijakan penetapan harga pada PT. Atrindo Asia Global sebagai berikut:

Semakin banyak kompetitor yang bergerak di bidang yang sejenis, sehingga menetapkan harga terlalu rendah tanpa memperhitungkan seberapa besar keuntungan yang akan diperoleh perusahaan sematamata untuk menarik atau mempertahankan pelanggan

Lupa atau tidak memasukan semua komponen biaya yang dikeluarkan bahkan hal-hal kecil setiap kali transaksi akan terakumulasi.

\section{Solusi}

Berdasarkan data dan temuan dari hasil penelitian, observasi, dan wawancara secara langsung terhadap narasumber, penulis ingin memberikan solusi pada PT. Atrindo Asia Global Bandung sebagai berikut:

1. PT. Atrindo Asia Global Bandung harus lebih mengetahui yang dibutuhkan oleh konsumen agar dapat memberikan penawaran paket harga yang tepat. Oleh sebab itu perusahaan dituntut untuk lebih kreatif memahami kebutuhan, keinginan, selera, dan motivasi konsumennya, serta menganalisis setiap tindakan para pesaing potensial dan implikasinya pada profitabilitas.

2 Meningkatkan strategi agar struktur biaya sulit ditiru oleh para pesaing minimal dalam jangka pendek. Penekanan biaya yang menghasilkan harga murah namun jasanya tidak memuaskan tidak akan berhasil. Oleh sebab itu perlu, sebagai perusahaan yang bergerak di bidang jasa dimana produk akhir merupakan kombinasi antara berbagai kinerja, praktik akuntansi tradisional cenderung tidak memadai, pendekatan $\mathrm{ABC}$ (Activity Based Costing) dinilai lebih cocok karena pendekatan ini berfokus pada sumber daya yang dikonsumsi oleh aktivitas-aktivitas spesifik yang berkaitan dengan penyelesaian produk akhir. Dengan demikian pendekatan ABC (Activity Based Costing) memungkinkan perusahaan mengidentifikasi aktivitas yang bernilai tambah dan aktivitas tak bernilai tambah.

3. PT. Atrindo Asia Global Bandung diharapkan menggunakan hitungan matematis terhadap biaya biaya yang dikeluarkan agar biaya yang akan dikeluarkan lebih tersusun secara sistematis dalam menyusun strategi-strategi pemasaran dalam jangka panjang. 
4. PT. Atrindo Asia Global Bandung lebih meningkatkan strategi harga dari segi permintaan pelanggan dan tidak menetapkan harga terlalu murah. Apabila jasa yang ditawarkan membutuhkan biaya waktu, biaya psikis, dan biaya pencarian, maka harga harus disesuaikan untuk mengkompensasi unsurunsur biaya non moneter. Sebaliknya apabila jasa yang dijual menghemat biaya waktu, biaya psikis dan biaya pencarian yang dipersepsikan konsumen, maka biasanya pelanggan cenderung lebih bersedia membayar harga moneter yang mahal.

\section{SIMPULAN DAN SARAN}

Berdasarkan hasil analisis penelitian mengenai kebijakan penetapan harga PT. Atrindo Asia Global Bandung, maka penulis dapat mengambil kesimpulan sebagai berikut:

1. Adapun pelaksanaan kebijakan penetapan harga pada PT. Atrindo Asia Global yaitu kebijakan penetapan harga yang diterapkan oleh PT. Atrindo Asia Global Bandung adalah metode penetapan harga dengan berdasarkan kepuasan (Satisfaction Based Pricing) dengan memberikan Garansi Jasa setelah 4 kali treatment inti dan memberikan daftar harga (Price List) serta memberikan in-house training kepada pelanggan. Metode berdasarkan hubungan atau relasi Kontrak dilakukan selama 1 tahun dan 6 bulan serta memberikan paket layanan jasa. Harga berdasarkan efisiensi dengan cara menekan biaya seefisien mungkin dan struktur biaya cukup sulit di tiru pesaing. Harga berdasarkan biaya yaitu menetapkan harga berdasarkan biaya-biaya yang dikeluarkan, menetapkan harga berdasarkan persaingan yaitu customary pricing dengan menetapkan harga secara standar serta menetapkan harga berdasarkan permintaan Memberikan discount sebesar $20 \%$ dan menetapkan harga sesuai dengan segmentasi pasar.

2. Adapun pelaksanaan kebijakan penetapan harga pada PT. Atrindo Asia Global yaitu kebijakan : penetapan harga yang diterapkan oleh PT. Atrindo Asia Global Bandung adalah metode penetapan harga dengan berdasarkan kepuasan (Satisfaction Based Pricing) dengan memberikan Garansi Jasa setelah 4 kali treatment inti dan memberikan daftar harga (Price List) serta memberikan in-house training kepada pelanggan. Metode berdasarkan hubungan atau relasi Kontrak dilakukan selama 1 tahun dan 6 bulan serta memberikan paket layanan jasa. Harga berdasarkan efisiensi dengan cara menekan biaya seefisien mungkin dan struktur biaya cukup sulit di tiru pesaing.
Harga berdasarkan biaya yaitu menetapkan harga berdasarkan biaya-biaya yang dikeluarkan, menetapkan harga berdasarkan persaingan yaitu customary pricing dengan menetapkan harga secara standar serta menetapkan harga berdasarkan permintaan Memberikan discount sebesar 20\% dan menetapkan harga sesuai dengan segmentasi pasar.

3. Adapun kendala yang dihadapi oleh PT. Atrindo Asia Global Bandung yaitu PT. Atrindo Asia Global seringkali menetapkan harga terlalu rendah tanpa memperhitungkan seberapa besar keuntungan yang akan diperoleh lupa atau tidak memasukan semua komponen biaya yang dikeluarkan bahkan hal-hal kecil setiap kali.

Adapun saran- saran yang direkomendasikan dari penelitian ini adalah sebagai berikut :

1. Penetapan harga pada PT. Atrindo Asia Global Bandung dapat disertai dengan perhitungan full cost, agar dapat mengefektif dan mengefisienkan biaya yang dikeluarkan serta dapat menghasilkan keuntungan yang lebih maksimum bagi perusahaan.

2. Meningkatkan strategi agar struktur biaya sulit ditiru oleh para pesaing minimal dalam jangka pendek. Penekanan biaya yang menghasilkan harga murah namun jasanya tidak memuaskan tidak akan berhasil. Oleh sebab itu perlu, sebagai perusahaan yang bergerak di bidang jasa dimana produk akhir merupakan kombinasi antara berbagai kinerja, praktik akuntansi tradisional cenderung tidak memadai, pendekatan ABC (Activity Based Costing) dinilai lebih cocok karena pendekatan ini berfokus pada sumber daya yang dikonsumsi oleh aktivitas-aktivitas spesifik yang berkaitan dengan penyelesaian produk akhir.

3. PT. Atrindo Asia Global perlu mempertimbangkan dengan cara memperhatikan kembali penetapan- penetapan harga yang digunakan sebagai rencana strategi pemasaran dalam jangka panjang. Sebab degan penetapan harga yang digunakan sekarang ini, dikhawatirkan para pesaing akan merebut pangsa pasar dan ini akan berdampak secara langsung terhadap keberlangsungan pada target penjualan, karena apabila target penjualan menurun laba atau pendapatan yang dihasilkan oleh perusahaan akan berkurang. 


\section{DAFTAR PUSTAKA}

1. Buku

Alma, Buchari. 2018. Manajemen Pemasaran dan Pemasaran Jasa. Bandung: Alfabeta. Jakarta: Penerbit Erlanggga.

Dharmmesta, Basu Swastha. 2014. Manajemen Pemasaran. Tangerang : Uniiversitas Terbuka.

Kotler dan Keller. 2014. Manajemen Pemasaran. Jasa, Prinsip, Penerapan dan Penelitian. Yogyakarta: Andi Publisher.

Malau, Harman. 2018. Manajemen Pemasaran. Bandung: Alfabeta.

Mursid, M. 2017. Manajemen Pemasaran. Jakarta: Bumi Aksara.

Nazir, Moh. 2013. Metode Penelitian Pemasaran. Bogor : Penerbit Ghalia Indonesia.

Noor, Juliansyah. 2014. Metodologi Penelitian. Jakarta: Prenadamedia Goup.

Dharmmesta, Basu Swastha. 2014. Manajemen Pemasaran. Tangerang : Uniiversitas Terbuka.

Sukardi. 2016. Metodologi Penelitian Pendidikan. Yogyakarta: Bumi Aksara.

Sugiyono, 2017. Metode Penelitian Kualitatif, Kuantitatif, $R$ dan D. Bandung: Alfabeta.

Tjiptono, Fandy. 2015. Strategi Pemasaran. Yogyakarta: Andi Publisher.

2. Jurnal

Dian Rini B dan Laelisneni. 2017. Analisis Penetapan Harga Jual dalam Perencanaan Laba Pada Home Industri Tempe Setia Budi Medan. Politeknik LP3I Medan.

Fuza, A. 2018. Pengaruh Penetapan Harga Terhadap Keputusan Pembelian Pada Rumah Batik Komar Di Cigadung Raya Timur Bandung. Universitas Pasundan Bandung.

I Ketut P dan Agus S. 2014. Analisis Penetapan Harga Jual Dalam Meningkatkan Laba Pada Rumah Makan Ulu Bete Laut Di Masamba Kabupaten Luwu Utara.

Sukarno D. 2015. Strategi Penetapan Harga Pada PT Madubaru Bantul. Universitas Negeri Yogyakarta.
You She M.A.D. 2017. Pengaruh Penetapan Harga dan Promosi Terhadap Tingkat Penjualan Tiket (Studi Kasus Pada Jasa Travel Agent di Wilayah Yogyakarta). Sekolah Tinggi Teknologi Kedirgantaraan. 